\title{
Protective Effect of Encapsulation in Fermentation of Limonene-contained Media and Orange Peel Hydrolyzate
}

\author{
Mohammad Pourbafrani ${ }^{1,2, *}$, Farid Talebnia ${ }^{1,2}$, Claes Niklasson ${ }^{2}$ \\ and Mohammad J. Taherzadeh ${ }^{1}$
}

1 School of Engineering, University of Borås, 50190 Borås, Sweden; E-mail: Farid.Talebnia@ @b.se;

E-Mail: Mohammad.Taherzadeh@hb.se

2 Chemical and Biological Engineering, Chalmers University of Technology, 41296 Göteborg,

Sweden; E-mail: Claesn@ chalmers.se

* Author to whom correspondence should be addressed; E-mail: Mohammad.Pour_Bafrani@hb.se;

Tel: +46-33-435 4361; Fax: +46-33-435 4008

Received: 21 June 2007; in revised form:19 July 2007 / Accepted:26 July 2007 /

Published: 7 August 2007

\begin{abstract}
This work deals with the application of encapsulation technology to eliminate inhibition by D-limonene in fermentation of orange wastes to ethanol. Orange peel was enzymatically hydrolyzed with cellulase and pectinase. However, fermentation of the released sugars in this hydrolyzate by freely suspended $S$. cerevisiae failed due to inhibition by limonene. On the other hand, encapsulation of $S$. cerevisiae in alginate membranes was a powerful tool to overcome the negative effects of limonene. The encapsulated cells were able to ferment the orange peel hydrolyzate in $7 \mathrm{~h}$, and produce ethanol with a yield of 0.44 $\mathrm{g} / \mathrm{g}$ fermentable sugars. Cultivation of the encapsulated yeast in defined medium was successful, even in the presence of $1.5 \%$ (v/v) limonene. The capsules' membranes were selectively permeable to the sugars and the other nutrients, but not limonene. While $1 \%(\mathrm{v} / \mathrm{v})$ limonene was present in the culture, its concentration inside the capsules was not more than $0.054 \%(\mathrm{v} / \mathrm{v})$.
\end{abstract}

Keywords: Orange peel, encapsulated yeast, alginate membrane, ethanol, limonene, enzymatic hydrolysis 


\section{Introduction}

The orange is one of the major citrus fruits and its production has increased since the 1980s. Orange production is predicted to approach 66.4 million tons by 2010 , representing a $14 \%$ increase within 12 years [1]. Approximately 40-60\% of oranges are squeezed to juice and the remainder, containing peel, segment membranes and other by-products is considered as citrus processing waste (hereafter referred to as orange peel for simplicity) [2]. Part of this waste is dried to be used as animal feed, but the drying process is costly due to the high moisture content of peels, and therefore a large proportion of waste has to be disposed of. This may result in many problems from both economic and environmental points of view including high transport costs, lack of disposal sites and high organic content [3]. Citrus processing residues contain both soluble and insoluble carbohydrates. The latter are present in the cell walls of the peels, particularly in the form of pectin, cellulose and hemicellulose. These polymers can be hydrolyzed enzymatically by cellulase, $\beta$-glucosidase and pectinase to their corresponding soluble carbohydrates [2,4].

Production of ethanol and other valuable products from fermentable sugars in peel hydrolyzate is an alternative to utilize industrial citrus processing waste and avoids the disposal-associated problems. However, the main obstacle to fermentation of orange peel is the presence of peel oil (more than $95 \%$ D-limonene, hereafter called limonene), a component that is extremely toxic to fermenting microorganisms. The antimicrobial effect of limonene was reported even at very low concentrations such as $0.01 \%(\mathrm{w} / \mathrm{v})$, and resulted in complete failure of fermentations at higher concentrations [5-7]. Therefore, a successful fermentation usually requires prior separation of limonene from the medium, by e.g. filtration or aeration [7,8]. Enclosing of yeast cells inside a selective and porous membrane through encapsulation could be a solution when toxic media are to be fermented. In the encapsulation method, a membrane is designed in which the nutrients and products can easily pass through while the toxic materials are excluded [9]. Encapsulation has already been presented as a powerful tool in fermentation of toxic lignocellulosic hydrolyzates, where strong inhibitors such as furfural were present in the culture [10].

The current work deals with the development of the encapsulation technique in fermentation of orange peel hydrolyzates in the presence of limonene, even at very high concentrations. In this method, yeast cells are confined within a hydrophilic membrane, which is theoretically impermeable to components with a hydrophobic nature like limonene [10]. The function of this membrane is to act as a selective barrier that protects the yeast cells and prevents them from being in direct contact with the toxic oil. The performance of encapsulated $S$. cerevisiae in both synthetic media containing high concentration of limonene and orange peel hydrolyzate and the membrane's selectivity were particularly investigated.

\section{Results and Discussion}

\subsection{Enzymatic Hydrolysis}

Hydrolysis of Argentina orange peel was carried out in both bioreactor and shake flask at $45{ }^{\circ} \mathrm{C}$ for $24 \mathrm{~h}$ with $12 \%$ solid concentration. The dry matter content of the peels was $20 \%( \pm 1.2 \%)$. However, the concentrations of more than $12 \%$ resulted in practical difficulties for efficient mixing in the 
bioreactor. The respective loadings of pectinase, cellulase and $\beta$-glucosidase were $1163 \mathrm{IU} / \mathrm{g}$, $0.24 \mathrm{FPU} / \mathrm{g}$ and $3.9 \mathrm{IU} / \mathrm{g}$ peel dry matter, based on optimized values previously reported for grapefruit peel [4]. The yields of sugars liberated after the hydrolysis are summarized in Table 1. There was no significant difference between the results from shake flask and the bioreactor. The released materials during the enzymatic hydrolysis were glucose, fructose, galactose, arabinose, xylose and galacturonic acid (GA).

Table 1. Yields of the carbohydrates released during enzymatic hydrolysis of the orange peels.

\begin{tabular}{|lc|}
\hline Carbohydrate & $\%$ (of total solid) \\
\hline Glucose & $22.9 \pm 2.4$ \\
Fructose & $14.1 \pm 1.3$ \\
Galactose & $4.0 \pm 0.2$ \\
Arabinose & $7.1 \pm 0.5$ \\
Xylose & $0.4 \pm 0.1$ \\
Galacturonic acid & $19.0 \pm 1.7$ \\
\hline Total & 67.5 \\
\hline
\end{tabular}

The sum of these sugars and sugar acid in hydrolyzate accounts for $67.5 \%$ of total solid content of the peels, where glucose, fructose and GA are the main three components present in hydrolyzate, corresponding to $84 \%$ of total sugars and sugar acid. The results obtained in the current work are similar to those reported previously by other researchers [4,7]. Concentration of limonene in the hydrolyzate was $0.52 \%(\mathrm{v} / \mathrm{v})$, which can be compared to limonene concentration of $1.4 \%$ (v/v) for Valencia peel hydrolyzate with $23 \%$ initial dry matter [7] .

\subsection{Free cell cultivation}

Anaerobic batch cultivations of "freely suspended" S. cerevisiae were carried out in synthetic medium containing $0,0.5,1$ and $1.5 \%(\mathrm{v} / \mathrm{v})$ of limonene, and the most important results are presented in Figures 1-2 and Table 2. The initial cell concentration in each flask was $3.6( \pm 0.3) \mathrm{g} / \mathrm{L}$ (approximately $10^{7}$ cells $/ \mathrm{mL}$ ). The suspended cells were not able to assimilate glucose in any of the media containing limonene at different concentrations. However, in the absence of limonene, the suspended cells were able to assimilate glucose completely in $12 \mathrm{~h}$ and produced ethanol with yield $0.41( \pm 0.03) \mathrm{g} / \mathrm{g}$ (Figures 1a,b and Table 2). 

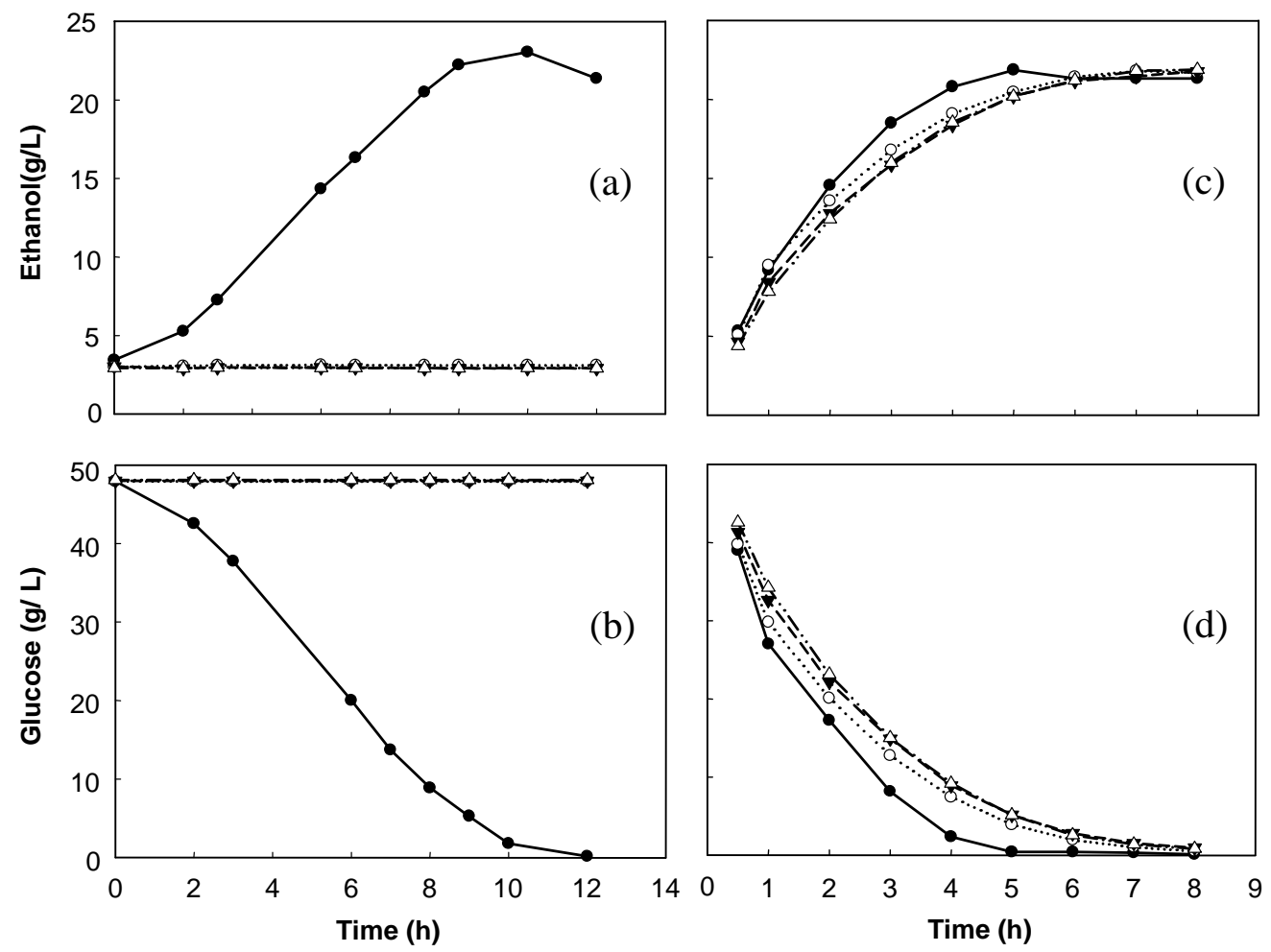

Figure 1. Glucose and ethanol concentration in anaerobic batch cultivation with suspended $(\mathrm{a}, \mathrm{b})$ and encapsulated $S$. cerevisiae (c,d), where limonene with different concentrations of $(\mathrm{v} / \mathrm{v}) 0 \%(\bullet), 0.5 \%(\circ), 1 \%(\mathbf{\nabla}), 1.5 \%(\Delta)$ was present in the culture.

The fraction of viable cells was estimated by the colony forming units' method (CFU) at different concentrations of limonene for suspended-cell system and is depicted in Figure 2.

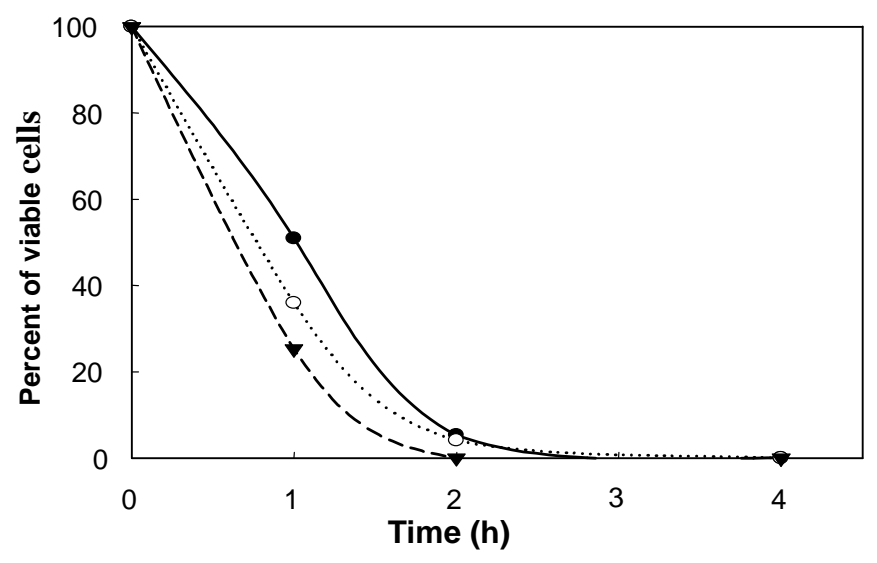

Figure 2. Effect of $0.5 \%(\bullet), 1 \%(0), 1.5 \%(\nabla)$ limonene on viability of $S$. cerevisiae in batch cultivation with suspended cells.

The fraction of viable cells in defined media containing $0.5,1$ and $1.5 \%(\mathrm{v} / \mathrm{v})$ of limonene decreased to 51,36 and $25 \%$ of the initial values, respectively, within $1 \mathrm{~h}$ cultivation. Furthermore, the number of viable cells for all media containing limonene was practically zero after $4 \mathrm{~h}$ cultivation. It indicates a high level of toxicity of limonene towards the strain of $S$. cerevisiae used. 


\subsection{Cultivation of encapsulated cells in the presence of limonene}

Anaerobic batch cultivations of encapsulated $S$. cerevisiae were carried out in synthetic medium containing 0, 0.5, 1 and $1.5 \%(\mathrm{v} / \mathrm{v})$ limonene. The most important results are presented in Figures $1 \mathrm{c}, \mathrm{d}$ and Table 2. A total volume of $25 \mathrm{~mL}$ encapsulated cells $(825 \pm 25$ capsules) in $100 \mathrm{~mL}$ defined medium was used, where $3.6( \pm 0.3) \mathrm{g} / \mathrm{L}$ of the cells were initially present in the capsules. It was similar in cultivation conditions to the suspended cells, in which the cells failed to assimilate glucose in any of the synthetic media containing limonene at different concentrations. However, cultivation of encapsulated cells was successful and glucose was assimilated even at very high limonene concentration of $1.5 \%(\mathrm{v} / \mathrm{v}$ ) (Figures 1c,d and Table 2). Cultivation in the limonene-free medium was completed in $5 \mathrm{~h}$, while the cultivations in the presence of 0.5 to $1.5 \%$ (v/v) limonene ended in $7 \mathrm{~h}$. On the other hand, increasing the limonene concentration in this range had practically no effect on fermentation time.

Table 2. Key rates and yields in anaerobic batch cultivation of suspended cells in limonene-free medium and encapsulated cells in media with various concentrations of limonene and peel hydrolyzates.

\begin{tabular}{|lcccccc|}
\hline \multirow{2}{*}{ Parameter } & $\begin{array}{c}\text { Suspended } \\
\text { Cells }\end{array}$ & \multicolumn{4}{c}{$\begin{array}{c}\text { Encapsulated cells with different limonene } \\
\text { concentration (\% v/v) of: }\end{array}$} & $\begin{array}{c}\text { Peel } \\
\text { hydrolyzate }\end{array}$ \\
\cline { 3 - 6 } & & $\mathbf{0}$ & $\mathbf{0 . 5}$ & $\mathbf{1}$ & $\mathbf{1 . 5}$ & \\
\hline $\mathrm{r}_{\mathrm{S}}(\mathrm{g} / \mathrm{L} . \mathrm{h})$ & 4.0 & 8.56 & 5.96 & 5.38 & 5.58 & 5.00 \\
$\mathrm{r}_{\mathrm{E}}(\mathrm{g} / \mathrm{L} . \mathrm{h})$ & 1.6 & 3.69 & 2.57 & 2.28 & 2.33 & 2.18 \\
$\mathrm{Y}_{\mathrm{SE}}(\mathrm{g} / \mathrm{g})$ & $0.41( \pm 0.03)$ & $0.43( \pm 0.02)$ & $0.43( \pm 0.01)$ & $0.42( \pm 0.01)$ & $0.42( \pm 0.01)$ & $0.44( \pm 0.01)$ \\
$\mathrm{Y}_{\mathrm{SGl}}(\mathrm{g} / \mathrm{g})$ & 0.080 & 0.062 & 0.050 & 0.048 & 0.047 & 0.050 \\
$\mathrm{Y}_{\mathrm{SAce}}(\mathrm{g} / \mathrm{g})$ & 0.018 & 0.017 & 0.016 & 0.016 & 0.015 & 0.017 \\
$\mathrm{Y}_{\mathrm{SSuc}}(\mathrm{g} / \mathrm{g})$ & 0.003 & 0.003 & 0.003 & 0.003 & 0.003 & 0.003 \\
\hline
\end{tabular}

*Notes: $-\mathrm{r}_{\mathrm{S}}$, volumetric glucose uptake rate; $\mathrm{r}_{\mathrm{E}}$, volumetric ethanol production rate; $\mathrm{Y}_{\mathrm{SE}}$, ethanol yield; $\mathrm{Y}_{\mathrm{SAce}}$, acetic acid yield; $\mathrm{Y}_{\mathrm{SSuc}}$, succinic acid yield; $\mathrm{Y}_{\mathrm{SGly}}$, glycerol yield

Ethanol production and glucose uptake rate were affected by the presence of limonene. Ethanol productivity in the media containing $0,0.5,1$, and $1.5 \%(\mathrm{v} / \mathrm{v})$ limonene was $3.69,2.57,2.28$ and $2.33 \mathrm{~g} / \mathrm{L} . \mathrm{h}$, respectively. It shows a clear difference between the presence and absence of limonene in the culture. However, the effect of increasing limonene concentration by threefold from 0.5 to $1.5 \%(\mathrm{v} / \mathrm{v})$ on the ethanol productivity might be in the range of experimental variation. On the other hand, ethanol productivity of the encapsulated cells in the presence of limonene was still higher than the corresponding value with the suspended cells in limonene-free medium (cf. Table 2).

Yield of ethanol produced was not significantly affected by the presence of limonene in the synthetic media and remained constant at $0.425( \pm 0.005) \mathrm{g} / \mathrm{g}$. Glycerol yield, on the other hand, was slightly decreased from 0.062 to $0.050 \mathrm{~g} / \mathrm{g}$ by the presence of $0.5 \%$ limonene. Further increase in limonene concentration, however, had a minor effect on reduction of glycerol yield. In general, 
glycerol yield was lower for encapsulated yeast cultivation compared to the corresponding value of $0.080 \mathrm{~g} / \mathrm{g}$ for suspended-cell cultivation. Acetic and succinic acids were also produced in all the cultivations, but in trace amounts, and no significant effect of limonene on their yield was observed (Table 2).

\subsection{Yeast cultivation in peel hydrolyzate}

Orange peels that were enzymatically hydrolyzed were supplemented with nutrients and anaerobically cultivated by both freely suspended and encapsulated $S$. cerevisiae in the bioreactor with total working volume of $1 \mathrm{~L}$ at $30{ }^{\circ} \mathrm{C}$. The hydrolyzate contained limonene whose concentration was measured as $0.52 \%(\mathrm{v} / \mathrm{v})$. The suspended cells were not able to ferment the peel hydrolyzate in $24 \mathrm{~h}$, where no sugars could be taken up by $S$. cerevisiae and no ethanol was produced.

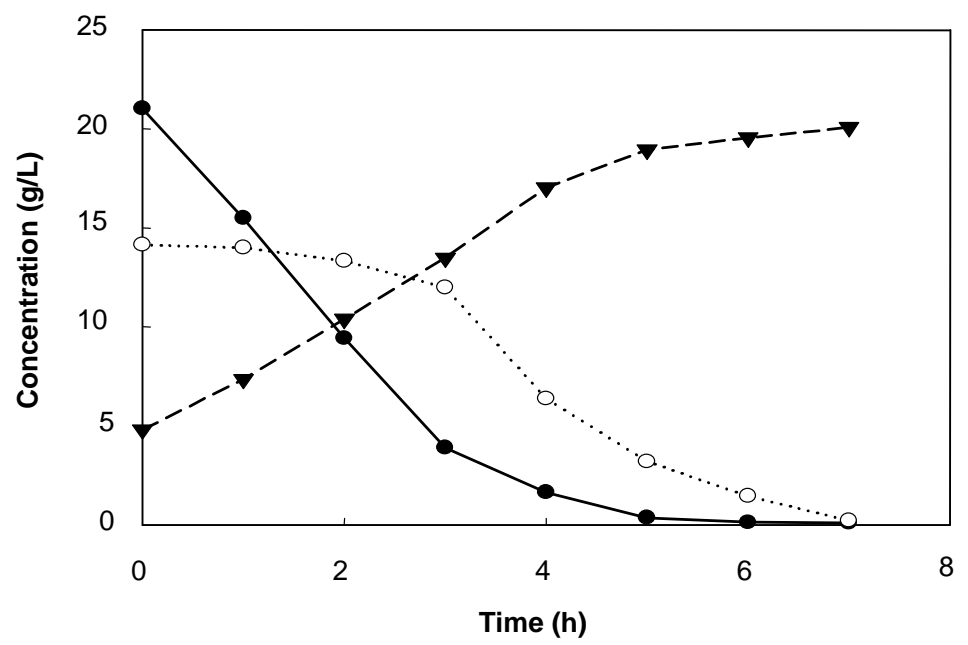

Figure 3. Profiles of glucose $(\bullet)$, fructose $(\circ)$ and ethanol $(\boldsymbol{\nabla})$ in cultivation of orange peel hydrolyzate by encapsulated $S$. cerevisiae.

Encapsulated S. cerevisiae successfully converted the fermentable sugars to ethanol and other metabolites. Among the sugars available in peel hydrolyzate, only glucose and fructose could be assimilated by the applied yeast strain and fermentation was completed within $7 \mathrm{~h}$. Consumption of fructose was delayed by the presence of glucose and the yeast started to take up fructose after the concentration of glucose approached below $5 \mathrm{~g} / \mathrm{L}$ (Figure 3). Ethanol yield based on total sugar consumption was $0.44( \pm 0.01) \mathrm{g} / \mathrm{g}$, and yields of glycerol, acetic and succinic acids were similar to the corresponding values of $0.5 \%(\mathrm{v} / \mathrm{v})$ limonene in synthetic medium (Table 2$)$.

\subsection{Selectivity of capsules' membrane:}

The liquid content of 350 capsules after crushing was used for determination of limonene by GCMS and the result showed a concentration of $0.054 \%(\mathrm{v} / \mathrm{v})$ of this toxic material inside the capsules. This result was also confirmed by the CFU test (Figure 4) where about $10^{5}$ cells/mL were found viable after $24 \mathrm{~h}$ incubation. It means that the viability of the encapsulated cells at this condition was stable at $8.5 \%( \pm 1.5 \%)$ within $4-24 \mathrm{~h}$ cultivation. This number is comparable to the viability of suspended cell at limonene concentration of 0.02 and $0.07 \%(\mathrm{v} / \mathrm{v})$ in the media. 


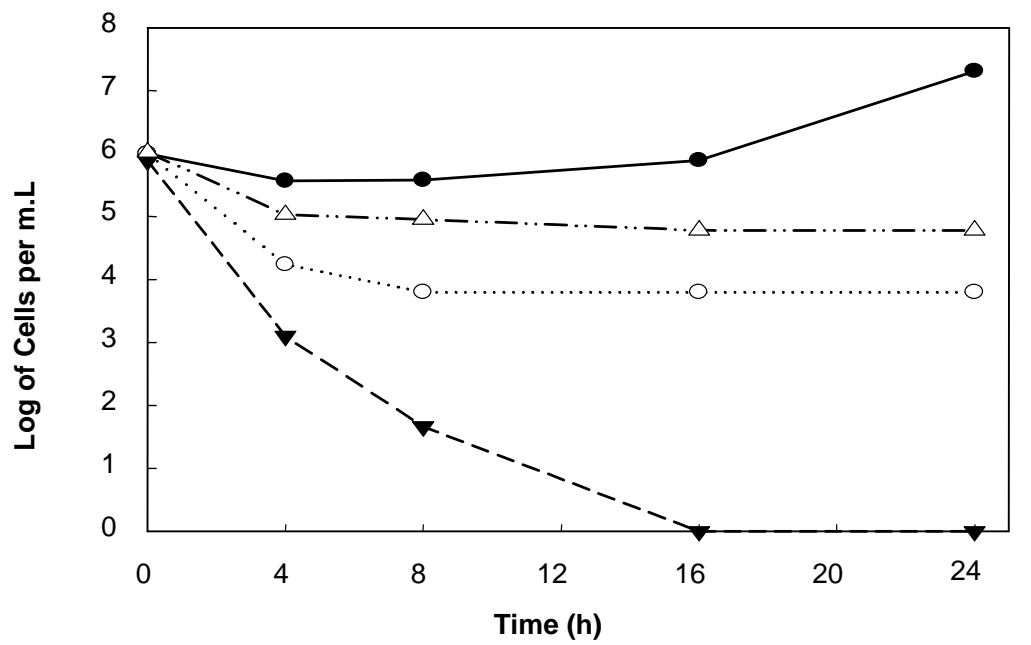

Figure 4. Effect of $0.02 \%(\bullet), 0.07 \%(\circ), 0.1 \%(\boldsymbol{\nabla})(\mathrm{v} / \mathrm{v})$ limonene on viability of suspended $S$. cerevisiae compared to $0.054 \%$ limonene $(\Delta)$ on the encapsulated yeast.

These results indicate that the suspended cells at initial concentration $10^{6}$ cells $/ \mathrm{mL}$ could tolerate the presence of $0.02 \%(\mathrm{v} / \mathrm{v})$ limonene in the medium even though the number of viable cells was slightly decreased in the first few hours and the growth of cells was delayed for $16 \mathrm{~h}$ (Figure 4). Media with 0.07 and $0.1 \%$ (v/v) of limonene were extremely harsh for S. cerevisiae, in which 98.3 and $99.8 \%$ of cells were not viable after $4 \mathrm{~h}$, respectively (Figure 4).

\subsection{Conclusions:}

Fermentation of orange peel hydrolyzate obtained from enzymatic hydrolysis in various solid concentrations was previously reported by freely suspended cells. However, fermentation was successful only at the lower solid concentration (2\%), while pretreatment to remove the existing limonene was reported as a demand at the higher solid concentration [7]. The lethal concentration of limonene is as low as $0.1 \%(\mathrm{v} / \mathrm{v})$. It is even a strong inhibitor at lower concentrations where the cells' viability is decreased within a few hours and the yeast population extensively decreases to a constant level (Figure 4). Yeasts are usually more sensitive to limonene than bacteria $[15,16]$ and minimum inhibitory concentration of limonene at $0.01 \%(\mathrm{w} / \mathrm{v})$ has been reported for S. cerevisiae [6]. However, this value may change depending on the medium $\mathrm{pH}$ [5]. Limonene is a hydrophobic component that can pass freely through the cell wall of yeast [17] and inhibit lipid body formation and accumulation inside the cell [18].

Preventing the cells from being in direct contact with limonene could be an efficient way to protect them from harsh environmental conditions such as organic solvent and poison. Encapsulation through which microbial cells are confined in a semi-permeable membrane is considered to be a promising method for cell retention but also for cell protection $[9,19]$. Due to the hydrophobic nature of limonene, it can be expected that alginate capsules' membrane would not be permeable to limonene, and fermentation should be possible regardless of the presence of limonene in the medium even at high concentration. If the capsules' membrane functions as an ideal selective barrier in which no passage of limonene occurs, then addition of limonene should not have any impact on cultivation with 
encapsulated cells. However, the results indicated that the fermentation rate and metabolite production were influenced by the presence of limonene in the media regardless of its concentration (Table 2). This fact suggests that limonene partially passes through the membrane and consequently can affect encapsulated yeast.

In conclusion, limonene has an enormous lethal effect on $S$. cerevisiae 8066. This fact indicates that practically no peel hydrolyzate can be fermented to ethanol without pretreatment. Application of encapsulated yeast, however, makes it possible to ferment peel hydrolyzate even with high limonene content. Although a minor amount of limonene penetrated into the capsules' interior and showed inhibitory effects, the yeast colonies inside the capsules were able to completely assimilate the sugars within $7 \mathrm{~h}$ even in a medium containing $1.5 \%(\mathrm{v} / \mathrm{v})$ limonene.

\section{Material and Methods}

\subsection{Substrates and enzymes}

The peels were residuals from Argentina orange obtained from Brämhults juice factory (Borås, Sweden) and stored frozen at $-20{ }^{\circ} \mathrm{C}$ until use. The frozen peel was thawed and ground with a food homogenizer (ULTRA-TURAX, TP 18-20, Janke \& Kunkel Ika-Labortechnik, Germany) to less than $2 \mathrm{~mm}$ in diameter. Total dry content of orange peel was determined by drying at $70{ }^{\circ} \mathrm{C}$ for $48 \mathrm{~h}$. Three commercial enzymes, Pectinase (Pectinex Ultra SP), Cellulase (Celluclast $1.5 \mathrm{~L}$ ) and $\beta$-glucosidase (Novozym 188), were provided by Novozymes A/S (Bagsvaerd, Denmark). Pectinase activity was measured by hydrolyzing $0.02 \%$ citrus pectin solution at $45{ }^{\circ} \mathrm{C}$ in $50 \mathrm{mM}$ sodium acetate buffer at pH 4.8 [4], and it was 283 international units (IU)/mg protein. Cellulase activity was determined based on a standard method provided by National Renewable Energy Laboratory [11], and was 0.12 filter paper units (FPU)/mg protein. Activity of $\beta$-glucosidase was $2.6 \mathrm{IU} / \mathrm{mg}$ solid as reported by the supplier.

\subsection{Hydrolyses}

Enzymatic hydrolyses of the peels were carried out in both shake flasks and a bioreactor (Biostat A., B. Braun Biotech, Germany). The experiment in shake flasks was performed to measure the concentration of sugars and limonene. In this case, ground peel was added into $250 \mathrm{~mL}$ conical flasks containing $50 \mathrm{mM}$ sodium acetate buffer at $\mathrm{pH} 4.8$ to make $100 \mathrm{~mL}$ of peel/water slurry with a solids concentration of $12 \%$. The flasks were then placed in a shaker bath at $45{ }^{\circ} \mathrm{C}$ and $140 \mathrm{rpm}$ for $24 \mathrm{~h}$. Higher volumes of hydrolyzates were prepared by hydrolysis of ground peel in the bioreactor with a working volume of $2 \mathrm{~L}$ and $12 \%$ solid concentration at $45{ }^{\circ} \mathrm{C}$ with stirring rate of $500 \mathrm{rpm}$ for $24 \mathrm{~h}$. The $\mathrm{pH}$ of the slurry was controlled at 4.8 by addition of $2 \mathrm{M} \mathrm{NaOH}$.

\subsection{Yeast Strain and Media}

The yeast S. cerevisiae CBS 8066, obtained from Centraalbureau voor Schimmelcultures (Delft, The Netherlands) was used in all experiments. The strain was maintained on agar plates made from yeast extract $(10 \mathrm{~g} / \mathrm{L})$, soy peptone $(20 \mathrm{~g} / \mathrm{L})$, and agar $(20 \mathrm{~g} / \mathrm{L})$ with D-glucose $(20 \mathrm{~g} / \mathrm{L})$ as an additional carbon source. The media used were either defined synthetic medium [12] containing glucose $(50 \mathrm{~g} / \mathrm{L})$ 
and $0,0.5,1$ and $1.5 \%(\mathrm{v} / \mathrm{v})$ of limonene (89188, Fluka, UK), or orange peel hydrolyzates supplemented with appropriate amounts of all the mineral salts and the trace elements to make the same composition as in synthetic medium.

\subsection{Encapsulation Method and Batch Cultivation Experiments}

The cells of $S$. cerevisiae were encapsulated using alginate-calcium membrane developed by Talebnia et al. [10], where yeast cells $(3.6 \mathrm{~g} / \mathrm{L})$ were present in the capsules at the beginning of the experiments. Furthermore, cultures of $3.6 \mathrm{~g} / \mathrm{L}$ freely suspended cells were provided for comparison with the encapsulated cells. These encapsulated and freely suspended cells were anaerobically cultivated in $100 \mathrm{~mL}$ defined medium containing $0,0.5,1$ and $1.5 \%(\mathrm{v} / \mathrm{v})$ limonene under identical conditions in $250 \mathrm{~mL}$ conical flasks. The flasks equipped with two stainless steel capillaries, and a glass tube with a loop trap, were used on the shaker bath at $30{ }^{\circ} \mathrm{C}$ and $140 \mathrm{rpm}$ for this set of experiments [13]. Fermentation of orange peel hydrolyzate was carried out in the bioreactor where temperature, stirring rate and $\mathrm{pH}$ were controlled at $30{ }^{\circ} \mathrm{C}, 200 \mathrm{rpm}$ and 5 , respectively. A total volume of $200 \mathrm{~mL}$ cell-seeded capsules after $16 \mathrm{~h}$ aerobic cultivation was added to bioreactor containing 800 $\mathrm{mL}$ hydrolyzate. Nitrogen gas was steadily sparged at the rate of $600 \mathrm{~mL} / \mathrm{min}$.

\subsection{Selectivity of capsules' membrane}

In order to characterize the selectivity of membrane, both direct and indirect methods were applied. The interior content of 350 capsules after mechanical rupture was utilized for GC-MS analysis where its oil content was previously extracted in $n$-heptane $(12 \mathrm{~mL})$. Through the indirect method, $25 \mathrm{~mL}$ of cell culture were cultivated in $100 \mathrm{~mL}$ synthetic media containing $0.02,0.07$ and $0.1 \%$ (v/v) of limonene to make an initial concentration of $10^{6}$ cells $/ \mathrm{mL}$. Then, the viability of cells was estimated with the colony forming units' method (CFU). A similar test was carried out where $25 \mathrm{~mL}$ of cell culture was encapsulated and added to $100 \mathrm{~mL}$ synthetic medium containing $1 \%(\mathrm{v} / \mathrm{v})$ limonene and the same initial cell concentration $\left(10^{6}\right.$ cells $\left./ \mathrm{min}\right)$.

\subsection{Analytical methods}

An Aminex HPX-87P ion-exchange column (Bio-Rad, USA) was used at $85{ }^{\circ} \mathrm{C}$ for estimation of glucose, galactose, arabinose, xylose and fructose concentrations. Ultra-pure water was used as eluent at a flow rate of $0.6 \mathrm{~mL} / \mathrm{min}$. Ethanol, acetic, galacturonic, succinic and pyruvic acids and glycerol concentrations were determined on an Aminex HPX-87H column (Bio-Rad, USA) at $60{ }^{\circ} \mathrm{C}$ using $5 \mathrm{mM} \mathrm{H}_{2} \mathrm{SO}_{4}$ at a flow rate of $0.6 \mathrm{~mL} / \mathrm{min}$. A refractive index (RI) detector (Waters 2414, Milipore, Milford, USA) and UV absorbance detector at $210 \mathrm{~nm}$ (Waters 2487) were used in series. Succinic acid was analyzed from UV chromatograms while the rest of metabolites were quantified from the RI chromatograms.

The cell viability and cell dry weight were determined according to Talebnia et al. [14]. The concentration of limonene was determined by addition of $n$-heptane ( $40 \mathrm{ml}, 99 \%$ purity) to the hydrolyzate $(100 \mathrm{ml})$ and centrifugation at $3500 \mathrm{~g}$ for $30 \mathrm{~min}$ to extract the oil. The resulting supernatant was then analyzed by a GC-MS (Hewlett Packard G1800C, Agilent, Palo Alto, CA) where 
the carrier gas was helium. The temperature was initially $50{ }^{\circ} \mathrm{C}$ and was increased to $250{ }^{\circ} \mathrm{C}$ at the rate of $15^{\circ} \mathrm{C} / \mathrm{min}$ and maintained at this temperature for $3 \mathrm{~min}$.

\section{Acknowledgments}

The authors appreciate foundation of Föreningssparbanken i Sjuhärad (Sweden) for financial support of this work and Dr. Dag Henriksson and Jonas Hanson for helping in the experimental works.

\section{References}

1. Plessas, S.; Bekatorou, A.; Koutinas, A.A.; Soupioni, M.; Banat, I.M.; Marchant, R. Use of Saccharomyces cerevisiae cells immobilized on orange peel as biocatalyst for alcoholic fermentation. Bioresour. Technol. 2007, 98, 860-865.

2. Grohmann, K.; Baldwin, E.A. Hydrolysis of Orange Peel with Pectinase and Cellulase Enzymes. Biotechnol. Lett. 1992, 14, 1169-1174.

3. Tripodo, M.M.; Lanuzza, F.; Micali, G.; Coppolino, R.; Nucita, F. Citrus waste recovery: a new environmentally friendly procedure to obtain animal feed. Bioresour. Technol. 2004, 91, 111-115.

4. Wilkins, M.R.; Widmer, W.W.; Grohmann, K.; Cameron, R.G. Hydrolysis of grapefruit peel waste with cellulase and pectinase enzymes. Bioresour. Technol. 2007, 98, 1596-1601.

5. Murdock, D.I.; Allen, W.E. Germicidal Effect of Orange Peel Oil and D-Limonene in Water and Orange Juice. Food Technol. 1960, 14, 441-445.

6. Winniczuk, P.P.; Parish, M.E. Minimum inhibitory concentrations of antimicrobials against micro-organisms related to citrus juice. Food Microbiol. 1997, 14, 373-381.

7. Grohmann, K.; Baldwin, E.A.; Buslig, B.S. Production of Ethanol from Enzymatically Hydrolyzed Orange Peel by the Yeast Saccharomyces-Cerevisiae. Appl. Biochem. Biotechnol. 1994, 45-6, 315327.

8. Lane, A.G. Removal of Peel Oil from Citrus Peel Press Liquors before Anaerobic-Digestion. Environ. Technol. Lett. 1983, 4, 65-72.

9. Park, J.K.; Chang, H.N. Microencapsulation of microbial cells. Biotechnol. Adv. 2000, 18, 303319.

10. Talebnia, F.; Niklasson, C.; Taherzadeh, M.J. Ethanol production from glucose and dilute-acid hydrolyzates by encapsulated S-cerevisiae. Biotechnol. Bioeng. 2005, 90, 345-353.

11. Decker, S.R.; Adney, W.S.; Jennings, E.; Vinzant, T.B.; Himmel, M.E. Automated filter paper assay for determination of cellulase activity. Appl. Biochem. Biotechnol. 2003, 105, 689-703.

12. Taherzadeh, M.J.; Liden, G.; Gustafsson, L.; Niklasson, C. The effects of pantothenate deficiency and acetate addition on anaerobic batch fermentation of glucose by Saccharomyces cerevisiae. Appl. Microbiol. Biotechnol. 1996, 46, 176-182.

13. Taherzadeh, M.J.; Eklund, R.; Gustafsson, L.; Niklasson, C.; Liden, G. Characterization and fermentation of dilute-acid hydrolyzates from wood. Ind. Eng. Chem. Res. 1997, 36, 4659-4665.

14. Talebnia, F.; Taherzadeh, M.J. In situ detoxification and continuous cultivation of dilute-acid hydrolyzate to ethanol by encapsulated S. cerevisiae. J. Biotechnol. 2006, 125, 377-384.

15. Sipailiene A.; Venskutonis P.R. ; Baranauskiene R.; Sarkinas A. Antimicrobial activity of commercial samples of thyme and marjoram oils. J. Essent. Oil Res. 2006, 18, 698-703. 
16. Subba, M.S.; Soumithri, T.C; Rao, R.S. Antimicrobial Action of Citrus Oils. J. Food Sci. 1967, 32, 225-227.

17. Bishop, J.R.P.; Nelson, G.; Lamb, J. Microencapsulation in yeast cells. J. Microencapsul. 1998, $15,761-773$.

18. Kimura, K.; Yamaoka, M.; Kamisaka, Y. Inhibition of Lipid Accumulation and Lipid Body Formation in Oleaginous Yeast by Effective Components in Spices, Carvacrol, Eugenol, Thymol, and Piperine J. Agric. Food Chem. 2006, 54, 3528-3534.

19. Chang, H.N.; Seong, G.H.; Yoo, I.K.; Park, J.K.; Seo, J.H. Microencapsulation of recombinant Saccharomyces cerevisiae cells with invertase activity in liquid-core alginate capsules. Biotechnol. Bioeng. 1996, 51, 157-162.

(C) 2007 by MDPI (http://www.mdpi.org). Reproduction is permitted for noncommercial purposes. 